\title{
Distribution and abundance of the giant clams (Cardiidae: Bivalvia) on Kei Islands, Maluku, Indonesia
}

\author{
TEDDY TRIANDIZA ${ }^{1,2}$, NEVIATY P. ZAMANI $^{2, \bullet}$, HAWIS MADDUPPA ${ }^{2}$, UDHI E. HERNAWAN $^{3}$ \\ ${ }^{1}$ Tual Technical Management Unit for Marine Life Conservation, Research Center for Oceanography, Indonesian Institute of Sciences. Jl. Merdeka, \\ Watdek, Southeast Moluccas 97611, Maluku, Indonesia. \\ ${ }^{2}$ Department of Marine Science and Technology, Faculty of Fisheries and Marine Science, Institut Pertanian Bogor. J1. Raya Dramaga, Bogor 16680, \\ West Java, Indonesia. Tel.: : +62 2518622909 - 8622911, Fax.: +62 2518622907 , `email: np_zamani@yahoo.com \\ ${ }^{3}$ Research Center for Oceanography, Indonesian Institute of Sciences. Jl. Ancol Timur, North Jakarta 14430, Jakarta, Indonesia
}

Manuscript received: 18 September 2018. Revision accepted: 27 February 2019.

\begin{abstract}
Triandiza T, Zamani NP, Madduppa H, Hernawan UE. 2019. Distribution and abundance of the giant clams (Cardiidae: Bivalvia) on Kei Islands, Maluku, Indonesia. Biodiversitas 20: 884-892. Giant clams, ecologically important bivalves in coral reefs, are under anthropogenic pressures in most parts of their range, necessitating the study of population status for conservation management. Here, we assessed species composition, distribution, size density, and habitat condition of giant clams in Kei Islands. A total of 9 reefs around the islands (Dar 1, Dar 2, Pulau Kur, Pulau Tanimbar Kei, Pulau Adranan, Pulau Dullah Laut, Difur, Labetawi, dan Ohoidertoom), were surveyed using quadrat-transect line in September-December 2017. We found five species of giant clams, i.e., Tridacna crocea, T. maxima, T. squamosa, T. noae, and Hippopus hippopus. Of these species, we report a new record for T. noae which was previously not known to be present in the region. The overall density was recorded at 0.0428 individual $/ \mathrm{m}^{2}$. Juveniles clams were fewer than the adults clam, this may indicate that the survival rate of recruit is low. Most individuals were found living on dead coral algae substrate $(75 \%)$. Based on the findings, this study suggests that giant clam population in Kei Islands are imperiled, indicated by low population density and local extinction for species $T$. gigas and T. derasa. It is recommended to establish a protected area and restocking of giant clams by through implementing sasi laut (traditional law) with a minimum period of 5 years.
\end{abstract}

Keywords: Exploitation, mature hermaphrodite, shell, Tridacna derasa, Tridacna gigas

\section{INTRODUCTION}

Giant clams are the biggest extant bivalves living in coral reefs in the Indo-Pacific (Lucas 1988). They live embedded in corals as well, sandy substrates or coral rubbles to a depth of up to 20 meters (Klumpp and Lucas 1994; Knop 1996; Ramah et al. 2017). Its geographical distribution lies from the southern part of Africa to Pitcairn Islands (Pacific Ocean) $\left(32^{\circ} \mathrm{E}-128^{\circ} \mathrm{W}\right)$ and widens from the northern part of Japan to the southern part of Australia $\left(24^{0} \mathrm{~N}-15^{\circ} \mathrm{S}\right)$ (bin Othman et al. 2010; Neo et al. 2017). This large geographical distribution of giant clams was likely due to the planktonic development phase which can reach nine days before turning into the benthic organism (Lucas 1988; Triandiza and Kusnadi 2013). Giant clams are a member of subfamily Tridacninae, family Cardiidae, consisting of two genera, namely Tridacna and Hippopus (Keys and Healy 2000). There are 12 extant species (Neo et al. 2017), of which eight can be found in Indonesia, i.e., Tridacna gigas, T. derasa, T. maxima, T. squamosa, T. crocea, T. noae, Hippopus hippopus, and H. porcelanus (Arbi 2010; Hernawan 2012; Borsa et al. 2015; Sadili et al. 2015).

Ecologically, giant clams are important as they significantly contribute to coral reef productivity (Soo and Todd 2014; Neo et al. 2015). Cabaitan et al. (2008) found that the abundance and diversity of fishes and other organisms in degraded coral reefs were affected by the presence of giant clams ( $T$. gigas). Siphonal tissue, feces, and gametes of giant clams are food sources for predators and detritivores (Jantshen et al. 2008; Neo et al. 2015). The shells are used by epibionts as substrates to colonize (MingoaLicuanan and Gomez 2002; Vicentuan-Cabaitan et al. 2014), while ectoparasites and commensalism live within the clams' mantle cavity (Neo et al. 2015). Their structurally complex shells are habitat for fishes to spawn, nurse, and shelter (Neo et al. 2015). Calcium carbonate produced by zooxanthellae living inside the mantle contributes to the structure and topography of coral reefs (Aline 2008; Neo et al. 2015). Giant clams also act as biofilter which can control eutrophication by filtering dissolved ammonia and nitrate in the water (Klumpp and Griffiths 1994; Neo et al. 2015).

Giant clams are iconic organisms. Not only ecologically important in coral reefs, but they also have high economic value, driving overexploitation of their population. The clam meat is great delicacies in some cultures. More than 2,000 shells were illegally traded with a total transaction of USD 45,000 within the last five years in Indonesia (Nijman et al. 2015). The shells are used as raw materials for the ceramic industry and handicrafts (Heslinga 1995; Wabnnitz et al. 2003). Furthermore, the juveniles are an important commodity for marine aquarium industry (Calumpong 1992; Heslinga 1995; Kinch 2002; Wabnitz et al. 2003; Gomez and Mingoa-Licuanan 2006; Neo and Loh 2014; Nijman et al. 2015).

The overexploitation has led to population decrease, not only in Indonesia but also in other regions such as 
Australia, Malaysia, Cambodia, and Philippines (Krell et al. 2011; Lee 2014; Colbeck 2015; Gomez 2015). Most population surveys in Indonesia reported that giant clams' densities were $>1$ per $\mathrm{m}^{2}$ (Capenberg 2007; Yusuf et al. 2009; Arbi 2010; Hernawan 2010; Naguit et al. 2012; Pada et al. 2013; Ode 2017; Wakum et al. 2017). Population decrease in the wild might be related to the abundance decrease, and the uneven species number found. Most of the surveys reported that most populations were dominated by $T$. crocea and $T$. maxima. Other species are very rare. In fact, it is believed that T. gigas has been in West Indonesia (Usher 1984; Wells 1997).

Kei Islands lie between $5^{\circ} 00^{\prime}-6^{\circ} 00^{\prime} \mathrm{S}$ and $131^{\circ} 45^{\prime}$ $133^{\circ} 15^{\prime} \mathrm{E}$. The islands are believed to have abundant marine resources since they are situated between Banda Sea and Arafura Sea (Hernawan 2010). Oceanographically, Kei Islands are affected by monsoon system especially southeast monsoon (Prawirowardoyo 1996). The movement of the southeast monsoon was presumed to trigger upwelling in Kei Islands waters increasing the ocean productivity. The region is geographically unique and ecologically dynamic which supports the complex and complete coastal ecosystem formation such as coral reefs, seagrass beds, and mangroves.

Giant clams are one of the endangered protected species (Eliata et al. 2003), that still can be found in Kei Islands waters (Kusnadi et al. 2008; Hernawan 2010; Hernawan et al. 2010). Traditionally, the coastal community on Kei Islands has utilized giant clams as a food source, construction materials, and cultural practices (Kusnadi et al. 2008). Fresh giant clams' meat was sold in the traditional markets for IDR 20,000 (observed in 2016).
Continuous exploitation without regard to sustainability will likely threaten the giant clams population in the wild as happened in Tongavera Lagoon, Cook Islands (Chambers 2007).

A population study of giant clams is necessary to understand their current status. Population data on giant clams in Kei Islands are very limited. As far as known, there have been only three reports: Kusnadi et al. (2008), Hernawan et al. (2010) and Triandiza and Kusnadi (2013). This study is aimed to gain data and information about the current status of giant clams in Kei Islands including their composition, distribution, density, size distribution, and habitat condition. The results from this study are expected to be the basis for giant clam management in Kei Islands.

\section{MATERIAL AND METHODS}

\section{Site description}

This study was conducted in Kei Islands waters, Southeast Moluccas from September to December 2017 and the sampling sites were located as follows: Dar 1 (S 05043'45.9"; E 132048'08.0"), Dar 2 (S 05044'20.2"; E $\left.132^{0} 48^{\prime} 07.4^{\prime \prime}\right)$, Kur Island (S 05017'07.1"; E 132001'21.5”), Tanimbar Kei Island (S 05059'13.29"; E 132027'53.28"), Adranan Island (S 05030'53.2"; E 132045'11.3"), Dullah Laut Island (S 05033'05.9"; E 132044'43.2"), Difur (S 05032'55.68"; E 132047'54.73”), Labetawi (S 05032'15.7"; E 132 46'41.7') and Ohoidertoom (S 05056'08.0"; E $\left.132^{0} 42^{\prime} 27.8^{\prime \prime}\right)$ (Figure 1). The study sites were determined based on the information from local fishermen and previous studies.

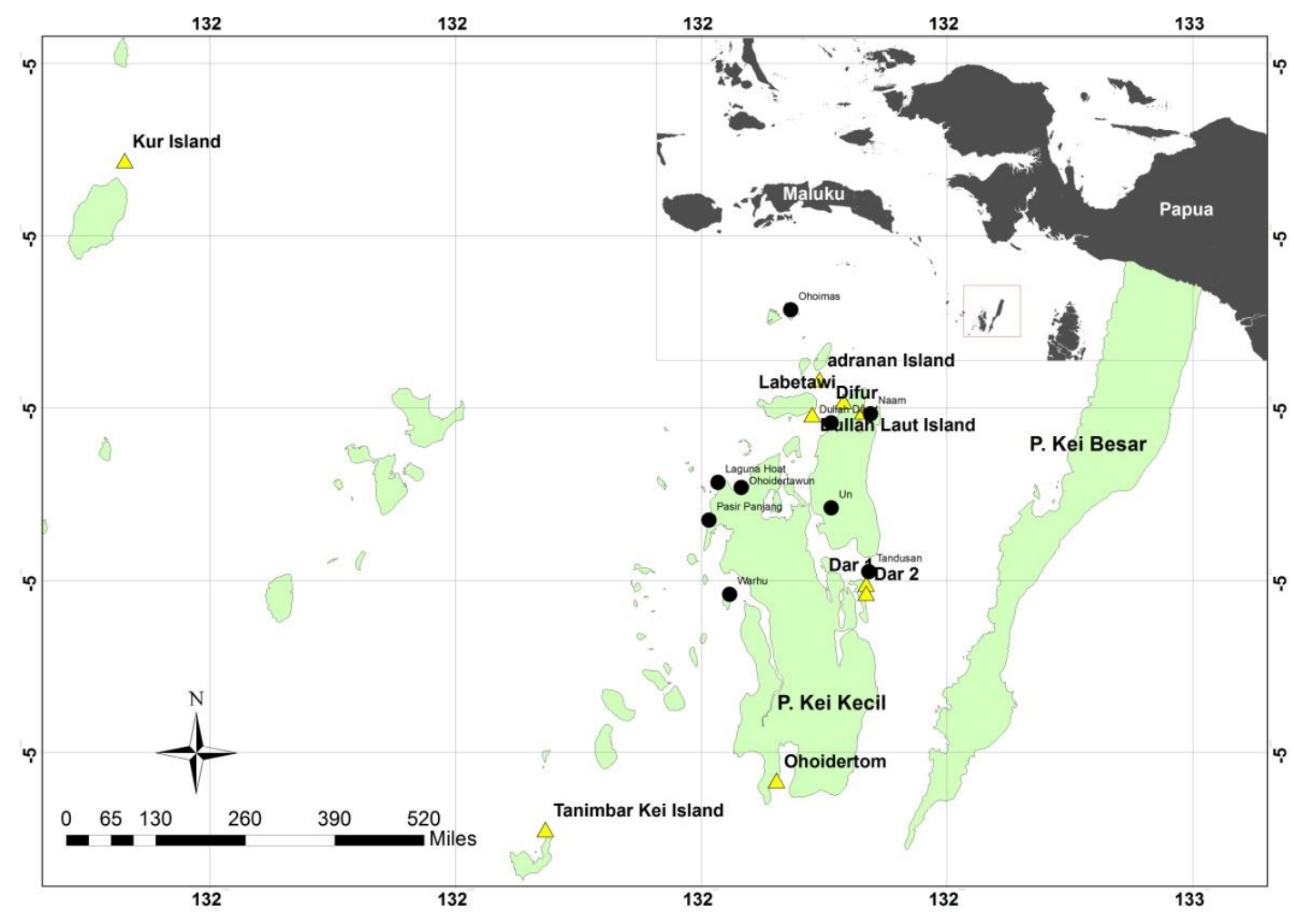

Figure 1. Study site locations in Kei Islands, Maluku, Indonesia; $\triangle$ : This study; : Hernawan (2010) 


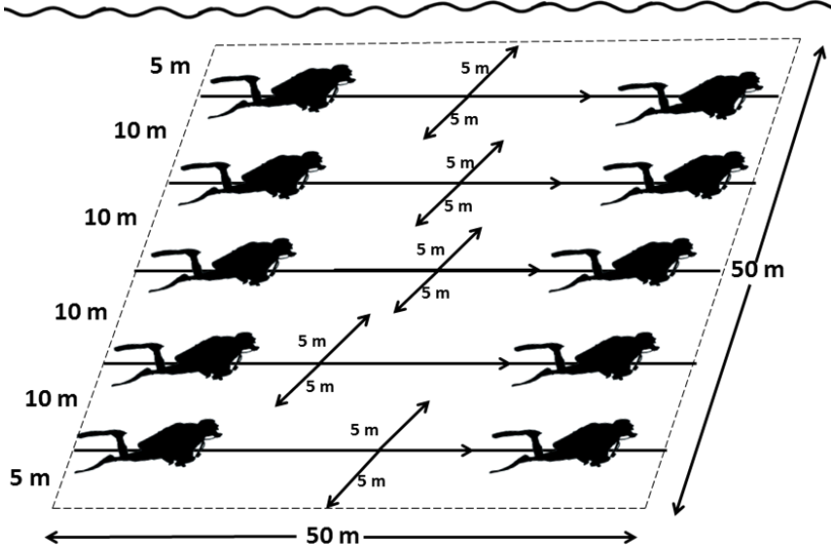

Figure 2. Sketch of Giant Clams Sampling Based on Chambers (2007). Source: http: //www.freevector.com/

\section{Sampling method}

The sampling method was conducted based on Chambers (2007) using quadrats-line transect, 50 × $50 \mathrm{~m}$ quadrats were placed in the sampling sites (a total of 2500 $\mathrm{m}^{2}$ ). Inside each quadrat were placed 5 line transects with $10 \mathrm{~m}$ intervals (Figure 2). Every giant clam found within 5 meters range from the left and right of line transect was recorded (species and number), and its shell length was measured. It was one quadrate randomly placed on the sampling site. As it was random, we did not consider the site position relative to the shore. The depths ranged from 1-5 meters. The substrate type was assessed visually, to differentiate each substrate category. Giant clams identification were made based on Copland and Lucas (1988) and Knop (1996).

Habitat condition assessment was refers to categories modified from English et al. (1994), namely: CC (coral covered) for living coral; DCA (dead coral algae) for dead coral; FAV (Faviidae) for family Faviidae; POR (Porites) for genus Porites; R (rubble) for dead coral rubble; and $\mathrm{S}$ (sand) for sand.

\section{Data analysis}

The calculation of giant clams density found in each sampling site was done using Snedecor and Cochran (1980) equation:

\section{$\mathbf{K}=\mathbf{D i} /(\mathbf{n i} \times \mathbf{A})$}
Where:
$\mathrm{K} \quad$ : density (individual $/ \mathrm{m}^{2}$ )
ni : Number of sampling site
Di : Number of population in all sampling sites
A : Size of each sampling site

Species composition was calculated by dividing the number of individuals of species by the total number of individuals in one sampling site. The size distribution was collected by gathering shell length data of each giant clam into the shell size classes with $5 \mathrm{~cm}$ interval in every class.
Developmental stages of giant clams life based on Fitt (1991), Manu and Sone (1995) and Beckvard (1981).

\section{RESULT AND DISCUSSION}

\section{Species composition}

Of eight species known to live in Indonesian waters (Neo et al. 2017; Borsa et al. 2015), four species were found during this study in Kei Islands, namely Tridacna crocea, T. squamosa, T. maxima, Hippopus hippopus; and one was T. noae (Figure 3). The number of species found in this study was lesser than previously reported by Hernawan (2010) which found six species in Kei Kecil Island waters, namely $T$. crocea, $T$. squamosa, T. maxima, T. derasa, T. gigas, and H. hippopus. Unfortunately, our study did not find $T$. gigas and $T$. derasa. This was in accordance with their endangered population status (Usher 1984; Wells 1997), and IUCN redlist categorized both of species in vulnerable (IUCN 2017). Poorten (2007) reported the results of Rumphius expedition in Ambon which found all species of giant clams (Cardiidae), except T. gigas. The results from researches in Indonesia showed that the presence $T$. gigas and $T$. derasa are usually limited to 1 or 2 individuals per survey (Yusuf et al. 2009; Hernawan 2010; Arbi 2010; Pada et al. 2013). Their population faces high exploitation pressure since they are the most wanted species in commercial trade (Gomez 2015; Larson 2016).

Tridacna noae is cryptic as it shares many similar morphological characteristics and habitat preferences as $T$. maxima, but its mantle ornaments are very distinctive which can be used to distinguish from $T$. maxima ( $\mathrm{Su}$ et al. 2014; Borsa et al. 2015; Neo and Low 2017). The mantle ornaments are characterized by separated oval-shaped patches with the whitish line on the edge. They have hyaline organs scattered along the mantle margin, and there is a clear presence of papillae (Figure 4) (Su et al. 2014; Borsa et al. 2015). The geographical distribution of T. noae extends from Ryukyus (South Japan), Taiwan, Southeast Asia, West Australia, and the Pacific Islands to about the east of Christmas Island (Borsa et al. 2014, Neo and Low 2017). In Indonesia, It was found in the Celebes Sea, the Molucca Sea and Savu Sea (Borsa et al. 2014). Our finding of the giant clam $T$. noae in Kei Islands adds to previously recorded species in Kei Islands (seven species in total). This finding also adds more information on the geographical distribution of this species in Indonesia.

Compared to other regions in Indonesia, Kei Islands have a considerably high number of giant clam species (Table 1). Only one species of giant clam that was not found in the Kei Islands namely $H$. porcellanus which can be found in the Raja Ampat (Wakum et al. 2017) and Southeast Sulawesi (Arbi 2010). The difference in species abundance might be related to habitat condition, level of exploitation, and sampling protocol. There was a positive relationship between reef flats condition, species diversity and species abundance (Capenberg 2007). Hernawan (2010) and Arbi (2010) showed that species abundance was 
affected by substrate types. Furthermore, species number was influenced by the level of exploitation from the local community (Hernawan 2010; Wakum et al. 2017; and Ode 2017). Van Wynsberge et al. (2016) stated that there was a relationship between the decreases of giant clam population with the presence of human population near the clams' population. Sites farther from residential areas had higher species number and abundance than those closer to residential areas (Hernawan 2010). The number and species might also be affected by the sampling protocol. Areas with a combination of reef flats and slopes showed higher species abundance than reef flats or reef slope area only (Susiana et al. 2014).

\section{Giant clams distribution and individual abundance}

The study recorded 964 giant clam individuals from nine sampling locations (Table 2). T. crocea and $T$. squamosa were found in all sampling locations, but the number of individuals varied widely. The study showed that $T$. crocea was the most abundant species (647 individuals; $67.12 \%$ ), while $T$. noae was the rarest one (7 individuals, $0.73 \%$ ) found only in one sampling site (Kur Island). Our finding was similar to the studies in other regions, where $T$. crocea was the most commonly observed species (Capenberg 2007; Hernawan 2010; Arbi 2010; Ode
2017; Wakum et al. 2017). The abundance of $T$. crocea might be related to its living behavior, which is by burying all of its shells into the hard substrate. The burrowing habit makes difficult for fisherman to harvest, thus relatively lower risk of exploitation compared to other species.

Based on the number of individuals recorded in each sampling location, Labetawi had the highest individual number (263 individuals; 3 species of giant clams), followed by Dar 1 (191 individuals; 4 species). While, Ohoidertoom was the location with the lowest number (15 individuals; 3 species). Labetawi was situated within many boulders, branching corals and coral rubbles. These substrates are very suitable for $T$. crocea, T.maxima, and $T$. squamosa (Mujiono 1988; Knop 1996). This variety of substrates can also be found in Dar 1. areas with the sandy substrate are often grown by seagrass which are ideals for H. hippopus and such areas can be found in Dar 1, Difur, Tanimbar Kei Island, and Adranan Island. Ohoidertoom was dominated by rocky surface and boulders overgrown with algae. This condition might not be ideal for giant clams leading to low species diversity and abundance at this location. Furthermore, the site is close to residential areas potentially allowing high anthropogenic influences (exploitation, pollution, habitat destruction, etc.).

Table 1. Giant clam comparison between Kei Island and other regions in Indonesia

\begin{tabular}{|c|c|c|c|c|c|c|c|c|}
\hline \multirow[b]{2}{*}{ Species } & \multicolumn{8}{|c|}{ Location } \\
\hline & Kei Islands & $\begin{array}{l}\text { Natuna \& } \\
\text { Anambas }\end{array}$ & $\begin{array}{l}\text { Derawan } \\
\text { Islands }\end{array}$ & $\begin{array}{l}\text { Seribu } \\
\text { Islands }\end{array}$ & Manado & Savu Sea & Kaimana & Morela \\
\hline Tridacna crocea & + & & + & + & + & + & + & + \\
\hline Tridacna maxima & + & + & + & + & + & + & + & + \\
\hline Tridacna squamosa & + & & + & + & + & + & + & + \\
\hline Tridacna derasa & $+*$ & & + & & & & & \\
\hline Tridacna gigas & $+*$ & & & & + & & + & + \\
\hline Tridacna noae & + & & & & & & & \\
\hline Hippopus hippopus & + & & & & & + & & + \\
\hline \multicolumn{9}{|l|}{ Hippopus porcellanus } \\
\hline References & $\begin{array}{l}\text { Hernawan } \\
(2010) ; \text { This } \\
\text { study; } \\
\text { *not found in }_{\text {not }} \\
\text { this study }\end{array}$ & $\begin{array}{l}\text { Tan and } \\
\text { Kastoro (2004) }\end{array}$ & $\begin{array}{l}\text { Capenberg } \\
(2007)\end{array}$ & $\begin{array}{l}\text { Yusuf et al. } \\
(2009)\end{array}$ & $\begin{array}{l}\text { Yusuf et al. } \\
\text { (2009) }\end{array}$ & $\begin{array}{l}\text { Naguit et } \\
\text { al. (2012) }\end{array}$ & $\begin{array}{l}\text { Pada et al. } \\
(2013)\end{array}$ & $\begin{array}{l}\text { Ode } \\
(2017)\end{array}$ \\
\hline
\end{tabular}

Table 2. Giant clam abundance in Kei Islands, Maluku, Indonesia (individual $/ 2500 \mathrm{~m}^{2}$ )

\begin{tabular}{|c|c|c|c|c|c|c|c|c|c|c|c|}
\hline \multirow{2}{*}{ Species } & \multicolumn{9}{|c|}{ Location } & \multirow{2}{*}{ Total } & \multirow{2}{*}{ Percentage $(\%)$} \\
\hline & $\mathbf{A}$ & $\mathbf{B}$ & $\mathbf{C}$ & D & $\mathbf{E}$ & $\mathbf{F}$ & $\mathbf{G}$ & $\mathbf{H}$ & I & & \\
\hline Tridacna crocea & 87 & 64 & 49 & 40 & 145 & 228 & 13 & 11 & $\checkmark 10$ & 647 & 67.12 \\
\hline Tridacna maxima & 74 & 47 & 12 & 3 & 7 & 11 & 0 & 11 & 1 & 166 & 17.22 \\
\hline Tridacna squamosa & 28 & 23 & 18 & 1 & 5 & 24 & 11 & 8 & 4 & 122 & 12.66 \\
\hline Tridacna noae & 0 & 0 & 7 & 0 & 0 & 0 & 0 & 0 & 0 & 7 & 0.73 \\
\hline Hipрориs hipрориs & 2 & 7 & 0 & 1 & 9 & 0 & 3 & 0 & 0 & 22 & 2.28 \\
\hline Total & 191 & 141 & 86 & 45 & 166 & 263 & 27 & 30 & 15 & 964 & 100 \\
\hline
\end{tabular}

Note: A. Dar 1, B. Dar 2, C. Kur Island, D. Difur, E. Tanimbar Kei Island, F. Labetawi, G. Adranan Island, H. Dullah Laut Island, I. Ohoidertoom 


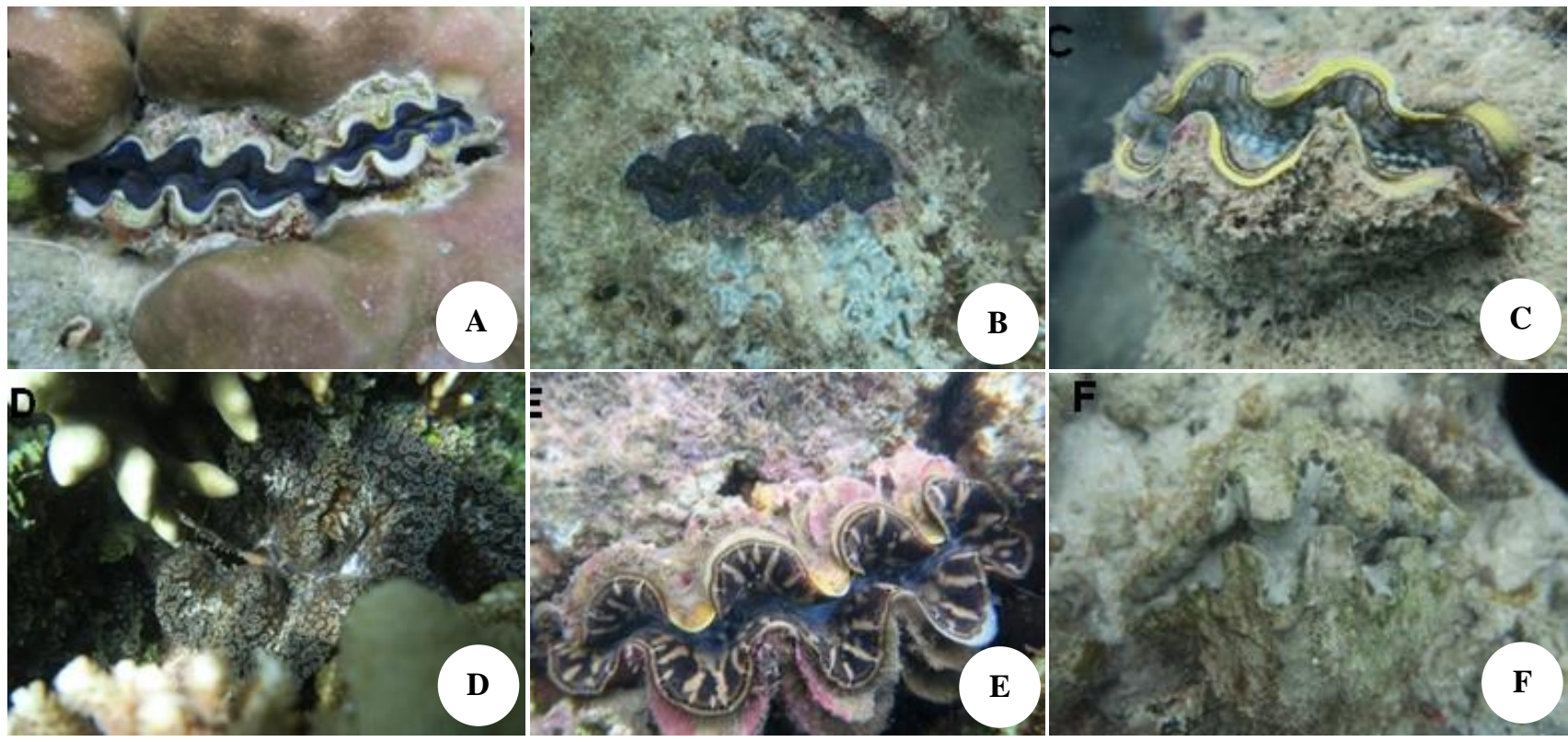

Figure 3. Giant clam species found in Kei Islands waters, Maluku, Indonesia: (A-B) Tridacna crocea, (C) T. maxima, (D) T. noae, (E) T. squamosa, (F) Hippopus hippopus

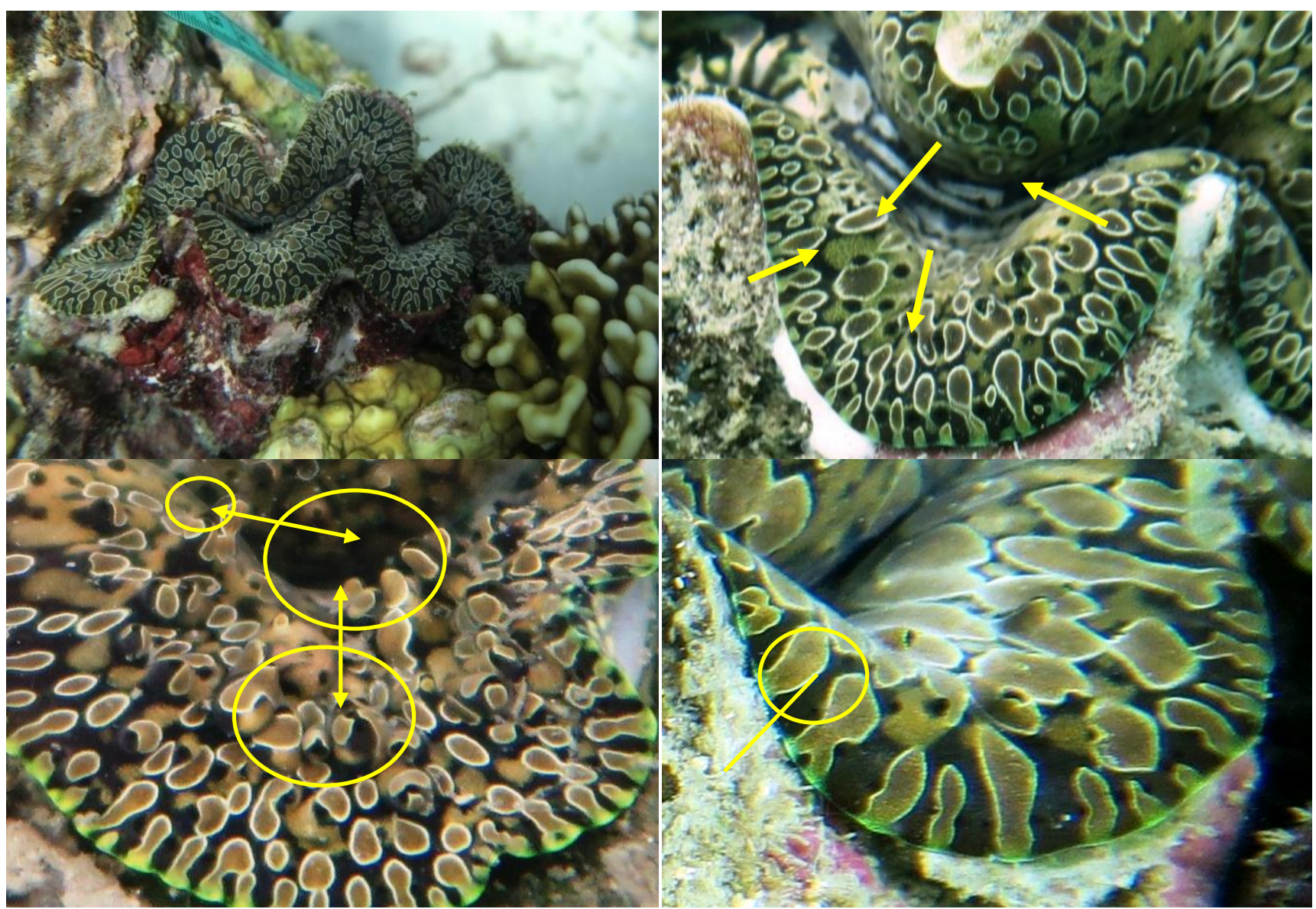

Figure 4. Mantle colors and ornaments of Tridacna noae from Kur Island, Kei Islands, Maluku, Indonesia (S 05 ${ }^{0} 17^{\prime} 07.1^{\prime \prime}$; E $\left.132^{0} 01 ' 21.5^{\prime \prime}\right) ;(\rightarrow)$ hyaline organs, $(\leftrightarrow)$ papillae, $(-)$ oval-shaped patches limited by white margins. 


\section{Giant clam species density}

Our study found that the overall density (pooled from all species and all locations) was 0.0428 individuals $/ \mathrm{m} 2$, meaning that there would be 428 giant clam individuals in a 1-hectare area (Table 2). Based on Planes et al. (1993), this population density was considered to be in a low category. This suggests that the giant clam population in the area may be facing extinction threat due to overexploitation pressure. Compared to a previous study by Hernawan (2010), the population density recorded in our study was relatively higher. Hernawan (2010) reported that the population density was 150 individuals/hectare $(0.015$ individuals $/ \mathrm{m} 2$ ). This, however, does not mean that the giant clam population in Kei Islands had increased because those studies had different sampling locations. Hernawan (2010) only covered Kei Kecil waters, while our study also covered the surrounding regions, such as Tanimbar Kei and Kur. Our study observed population increase in $T$. crocea (non-target species), while highly commercial species T.gigas and T. derasa were not found.

Giant clam population density in Kei Islands was lower than in some other regions, for example 0.53 individuals $/ \mathrm{m}^{2}$ was reported in North Sulawesi (Arbi 2010), 0.2 individuals $/ \mathrm{m}^{2}$ in Gaya East-Reef Flat, Sabah, Malaysia (Montagne et al. 2013), 0.1-2.0 individuals $/ \mathrm{m}^{2}$ in Giang Bo Reef, Vietnam (Latypov 2013), 0.13-0.72 individuals $/ \mathrm{m}^{2}$ in Kong Rong Archipelago, Cambodia (Savage et al. 2013), 4.15-158 individuals $/ \mathrm{m}^{2}$ in Mermaid Reef, Northwest Australia (Rees et al. 2003), and 0.001-0.03 individuals $/ \mathrm{m}^{2 \mathrm{in}}$ the Indian Ocean and Southeast Asia (Besker 1991; Apte et al. 2010; Ramah et al. 2018). The difference in population density might result from variations in substrate conditions, exploitation pressures and whether the area is protected or not. Hernawan (2010) observed higher population density in locations with varied substrates. Gonjales et al. (2014) reported that protected areas had higher species diversity and abundance compared to unprotected areas.

Giant clams $T$. crocea showed the highest population density $\left(0.0288\right.$ individuals $\left./ \mathrm{m}^{2}\right)$, while the lowest density was found within the T. noae and H. Hippopus population (0.00031 individuals $/ \mathrm{m}^{2}$ and 0,00098 individuals $/ \mathrm{m}^{2}$ respectively). Our finding showed that $T$. crocea has the highest population density which is confirmed by previous studies, such as Wakum et al. (2017) in the Amdui waters Raja Ampat, Latypov (2013) in Giong Bo Reef Vietnam, Naguit et al. (2012) in the Savu Sea East Nusa Tenggara, and Arbi (2010) in the North Sulawesi. Due to its small size and living behavior, T. crocea is the least targeted species, making it less vulnerable to harvesting. Thus its population remains higher than the other giant clam species.

The low population density in $T$. noae was likely due to its limited distribution. H. hippopus showed low population density as well because it is highly exploited. In Pari Island, $H$. hippopus had decreased $84 \%$ from 1984 until 2003 (Eliata et al. 2003). Yusuf et al. (2009) did not find $H$. hippopus in the Seribu Islands. Dolorosa and Schoppe (2005) reported the density of H. hippopus had decreased 97\% from 1995 to 2005 in Tubbataha Reef Park Philippines.

Tabel 3. Giant clams density (individual $/ \mathrm{m}^{2}$ ) in Kei Islands, Maluku, Indonesia

\begin{tabular}{lcccccccccc}
\hline \multirow{2}{*}{ Species } & \multicolumn{1}{c}{ Location } & \multicolumn{1}{c}{ Total } \\
\cline { 2 - 8 } & $\mathbf{A}$ & $\mathbf{B}$ & $\mathbf{C}$ & $\mathbf{D}$ & $\mathbf{E}$ & $\mathbf{F}$ & $\mathbf{G}$ & $\mathbf{H}$ & $\mathbf{I}$ & \\
\hline Tridacna crocea & 0.0348 & 0.0256 & 0.0196 & 0.016 & 0.058 & 0.0912 & 0.0052 & 0.0044 & 0.004 & 0.0288 \\
Tridacna maxima & 0.0296 & 0.0188 & 0.0048 & 0.0012 & 0.0028 & 0.0044 & 0 & 0.0044 & 0.0004 & 0.0074 \\
Tridacna squamosa & 0.0112 & 0.0092 & 0.0072 & 0.0004 & 0.002 & 0.0096 & 0.0044 & 0.0032 & 0.0016 & 0.0054 \\
Tridacna noae & 0 & 0 & 0.0028 & 0 & 0 & 0 & 0 & 0 & 0 & 0.0003 \\
Hippopus hippopus & 0.0008 & 0.0028 & 0 & 0.0004 & 0.0036 & 0 & 0.0012 & 0 & 0 & 0.00098 \\
Total & 0.0764 & 0.0564 & 0.0344 & 0.018 & 0.0664 & 0.1052 & 0.0108 & 0.012 & 0.006 & 0.0428 \\
\hline
\end{tabular}

Note: A. Dar 1, B. Dar 2, C. Kur Island, D. Difur, E. Tanimbar Kei Island, F. Labetawi, G. Adranan Island, H. Dullah Laut Island, I. Ohoidertoom.

Table 4. Giant clams shell length composition in Kei Islands, Maluku, Indonesia

\begin{tabular}{|c|c|c|c|c|c|c|c|c|c|c|}
\hline \multirow[b]{2}{*}{ Life stage } & \multicolumn{2}{|c|}{ T. crocea } & \multicolumn{2}{|c|}{ T. maxima } & \multicolumn{2}{|c|}{ T. squamosa } & \multicolumn{2}{|c|}{ T. noae } & \multicolumn{2}{|c|}{ H. hippopus } \\
\hline & $\begin{array}{c}\text { Shell } \\
\text { size (Fitt } \\
\text { 1991) }\end{array}$ & $\begin{array}{c}\text { Ind. } \\
\text { number }\end{array}$ & $\begin{array}{l}\text { Shell size } \\
\text { (Manu } \\
\text { and Sone } \\
\text { 1995) }\end{array}$ & $\begin{array}{c}\text { Ind. } \\
\text { number }\end{array}$ & $\begin{array}{c}\text { Shell size } \\
\text { (Becvart } \\
\text { 1981) }\end{array}$ & $\begin{array}{c}\text { Ind. } \\
\text { number }\end{array}$ & $\begin{array}{l}\text { Shell size } \\
\text { (Manu } \\
\text { and Sone } \\
\text { 1995) }\end{array}$ & $\begin{array}{c}\text { Ind. } \\
\text { number }\end{array}$ & $\begin{array}{l}\text { Shell size } \\
\text { (Fitt 1991) }\end{array}$ & $\begin{array}{c}\text { Ind. } \\
\text { number }\end{array}$ \\
\hline Juvenil & $<2 \mathrm{~cm}$ & 20 & $<4 \mathrm{~cm}$ & 1 & $<10 \mathrm{~cm}$ & 22 & $<4 \mathrm{~cm}$ & & $<7 \mathrm{~cm}$ & 0 \\
\hline Young adult & $2-4 \mathrm{~cm}$ & 118 & $4-15 \mathrm{~cm}$ & 159 & $10-20 \mathrm{~cm}$ & 73 & $4-15 \mathrm{~cm}$ & 3 & $7-13 \mathrm{~cm}$ & 4 \\
\hline $\begin{array}{l}\text { Mature } \\
\text { hermaphrodite }\end{array}$ & $>4 \mathrm{~cm}$ & 509 & $>15 \mathrm{~cm}$ & 9 & $>20$ & 27 & $>15 \mathrm{~cm}$ & 4 & $>13$ & 18 \\
\hline Average length & & $7.24 \pm 3.13$ & & $15.27 \pm 6.26$ & & $9.95 \pm 3.25$ & & $15.71 \pm 4.27$ & & $21 \pm 9.37$ \\
\hline Max. length & & 16 & & 29 & & 20 & & 20 & & 35 \\
\hline Min. length & & 1 & & 3 & & 2 & & 11 & & 4 \\
\hline
\end{tabular}




\section{Shell length composition}

The results of the shell size composition for each giant clam in the study site are shown in Table 4. The measurement results of the entire giant clams population indicated that $T$. crocea had the narrowest shell size, with a shell length range of $1-16 \mathrm{~cm}$ and a total average length of $7.24 \pm 3.13 \mathrm{~cm}$ whereas $H$. hippopus had the largest measured shell size, which ranged from 4 to $35 \mathrm{~cm}$ and a total average length of $21 \pm 9.37 \mathrm{~cm}$. Rosewater (1965) reported that $T$. crocea were the smallest giant clams, with a maximum length of $15 \mathrm{~cm}$, but commonly sized at $10 \mathrm{~cm}$ (Poutiers 1998). The sizes of H. hippopus shells found at the study sites were relatively smaller compared to that reported by Poutiers (1998) which could grow up to $40 \mathrm{~cm}$. Mingoa-Licuanan and Gomez (2002) reported the sizes of $H$. hippopus shells at the Bolinoa Marine Laboratory, Philippines reached $50 \mathrm{~cm}$. However, the average length of $H$. hippopus shell obtained was similar to the common length reported by Doloroso et al. (2014) and Poutiers (1998).

Based on the shell size, generally the most common giant clam individuals found in Kei Islands waters were in the mature hermaphrodite, i.e., $T$. crocea 509 individual (79\%), T. noae 4 individual (57\%) and H. hippopus 18 individual $(82 \%)$. In contrast, majority of the individual of T. maxima 159 individual $(94 \%)$ and $T$. squamosa 73 individual $(60 \%)$ were in the young adult phase. Individual in the juvenile phase were fewer compared to the number of individuals in the young adult and mature adult phases, only $18 \%$ in $T$. squamosa, $3 \%$ in T. crocea and $1 \%$ in $T$. maxima. Moreover, giant clams $T$. noae and $H$. hippopus were not found in the juvenile phase in this study. The low number of clam on juvenile phase found may mean a low juvenile recruitment process or a low survival. The recruitment process is one of the keys to the conservation of giant clam populations. The low of the recruitment process can have implications for the extinction of giant clams population in Kei Islands waters, especially when it continuously occurred with the addition of anthropogenic pressure by humans.

Low recruitment rate in giant clams can be caused by various factors. Pearson and Munro (1991) stated that the unfavorable habitat conditions can affect the recruitment process, especially in the process of attaching giant clam larvae to the substrate. Ocean current patterns could affect recruitment process of giant clams because it had the potential to limit the larvae dispersal and gene flow, temporally and spatially (Rovago-Gotanco et al. 2007; White et al. 2010). Neo et al. (2013) stated that the poor rates of fertilization affected the distribution and population density of giant clams. Roegner (2000) stated the level of recruitment in mollusks depended on the pattern larvae dispersal from spawning to the settlement to the substrate. Explanation of the recruitment failure in giant clams population in Kei Islands was not yet known with certainty, further research is needed.

\section{Giant clams habitat}

Giant clams inhabit the area of coral reefs by attaching their shells in coral, sand or rock substrate. In Kei Islands waters, giant clams were found to live on six types of substrate, namely $1 \%$ on live coral cover (CC), $75 \%$ on dead coral algae (DCA), $2 \%$ on coral Faviidae (FAV), 17\% on coral genus Porites (POR), 2\% on coral rubbles (RB) and $3 \%$ on sand substrate (S). The results of substrate assessment for each species of giant clams can be seen in Figure 6.

Tridacna crocea were mostly found living on the dead coral algae substrate (85\%). Another small part was found in the boulder of the corals genus Porites (12\%) and corals family Faviidae (1\%). Fartherree (2006) stated that $T$. crocea had a living behavior that embeds all of its shells in living or dead coral boulder by drilling corals using movements on the shell hinge assisted by its byssal orifices which produced organic acids to dissolve the substrate, therefore $T$. crocea is requiring a hard substrate as their habitats, such as DCA and POR type of substrates. T. maxima were found on the dead coral algae substrate by $72 \%$ and the boulder of corals genus Porites by $28 \%$. T. maxima's living behavior was almost the same as $T$. crocea which was to burrow their shells in the substrate, but $T$. maxima only buried half of its shell into a boulder substrate (Mudjiono 1988). Species T. noae were only found on dead coral algae substrate (100\%).

Tridacna squamosa was observed on more diverse habitat choices compared to the other species. This species was found in six types of substrate, namely dead coral algae $(41 \%)$, corals genus Porites $(31 \%)$, sand $(11 \%)$, coral rubbles $(9 \%)$, live coral covered (6\%), and corals family Faviidae (2\%). T. squamosa can easily attach its byssus to any substrate so it could live on various substrates such as dead or living coral, coral rubbles and sand (Knob 1996; Calumpong1992). H. hippopus was mostly found on a sandy substrate (72\%) and the rest was found on coral rubbles (28\%). Some $H$. hippopus were also found in seagrass beds. In the Tanimbar Kai sampling site, $H$. hippopus was found in seagrass Thallasodendron ciliatum and Halophila ovalis. It was in accordance with Hernawan (2010) and Arbi (2010) who also found H. hippopus in seagrass beds. Based on Harzhauser et al. (2008) the ancestors of the bivalve Tridacninae lived in seagrass beds, and not on coral reefs.

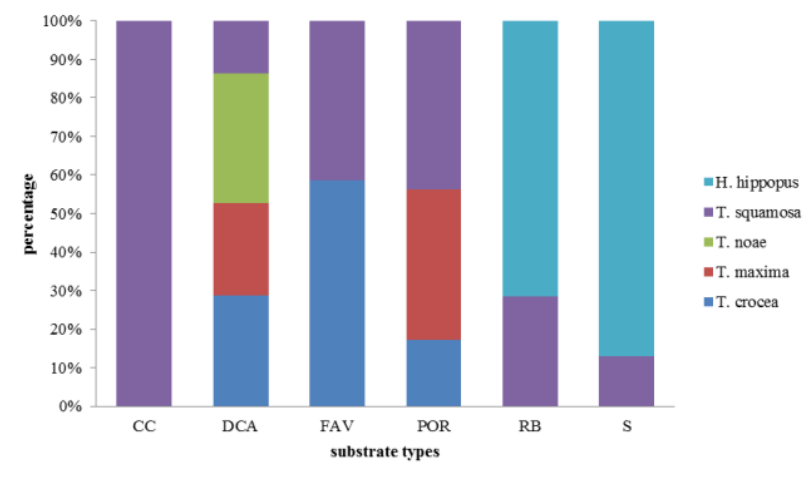

Figure 6. Substrate type associated with giant clam species in Kei Islands Waters, Maluku, Indonesia. Note: CC: coral cover, DCA: dead coral algae, FAV: coral Faviidae, POR: coral genus Porites, $\mathrm{RB}$ : coral rubbles, $\mathrm{S}$ : sand substrate 


\section{Implication for giant clams conservation effort}

Our study shows that the giant clams population in Kei Islands is imperiled, indicated by low population density and decreased species number. T. gigas and T. derasa were previously observed but were not found in our study, indicating local extinction of these two species. Furthermore, our study also found that most of the giant clams were adult. The number of juveniles is lower than adults. This may indicate that recruitment does occur, however, the survival rate may be low. These situations might likely be due to overexploitation and effective conservation measure needs to be taken immediately, both by the local government and the community. Though giant clams have been listed as protected species under national law, a protected area designated for giant clams is needed in Kei Islands and the local government should initiate the designation of this conservation area. Studies reported that giant clam conservation area could increase the abundance and species diversity of giant clams and other association organisms (Cabaitan et al. 2008; Gonjales et al. 2014). In addition, giant clams conservation efforts require special measures that are focused on increasing individual density and restoring the juvenile/adult ratio. This can be done by restocking program. Based on this study, the most suitable area for protected area and restocking were Dar, Tanimbar Kei Island, and Kur Island, as these locations have good substrate variation with relatively remote distance from residential areas. Traditional practice of sasi may also help restore giant clam population in all studied locations, by limiting harvesting time in a specific period. We suggest that sasi can be imposed for 5 years, since giant clams generally take years to reach adulthood (Bacvard 1981; Fitt 1991).

\section{ACKNOWLEDGEMENTS}

We thank UPT Loka Konservasi Biota Laut Tual for Facilitating sample collection for this study. We would also like to thank Abdul Kadir Yamko, Aliyadi, Ahmad Ainarwowan, Rosmi Nuslah Pesilette, Roni Nahusona, and Bikri Rahman Pary for their field assistance.

\section{REFERENCES}

Aline T. 2008. Dissolution of dead corals by euendolithic microorganisms across the northern Great Barrier Reef (Australia). Microb Ecol 55: 569-580.

Apte D, Dutta S, Babu I. 2010. Monitoring densities of the giant clam Tridacna maxima in the Lakshadweep Archipelago. Mar Biodivers 3: $1-9$.

Arbi UY. 2010. Kepadatan dan kondisi habitat kerang kima (Cardiidae: Tridacninae) di beberapa lokasi di Perairan Sulawesi Utara. Bawal 3 (2): 139-148. [Indonesian]

Bin Othman AS, Goh GHS,Todd PA. 2010. The distribution and status of giant clams (Family Tridacnidae), a short review. Raffles Bull Zool 58 (1): 103-111.

Borsa P, Fauvelot C, Tiavouane J, Grulois D, Wabnitz C, Naguit MRA, Andrefouet S. 2015. Distribution of Noah's giant clam, Tridacna noae. Mar Biodivers 45, 339-344.

Cabaitan PC, Gomez ED, Alino PM. 2008. Effects of coral transplantation and giant clam restocking on the structure of fish communities on degraded patch reefs. J Exp Mar Biol Ecol 357, 85-98.
Calumpong HP. 1992. The Giant Clam: An Ocean Culture Manual. ACIAR Monograph 16. Canberra.

Chambers CNL. 2007. Pausa (Tridacna maxima) in Tongareva Lagoon, Cook Islands. SPC Information Bulletin 3: 7-12.

Colbeck R. 2015. Clams to help slam trade shut. Australian Fisheries Management Authority. http: //www.afma.gov.au/clams-help-slamtrade-shut/.

Copland JW, Lucas JS.1988. Giant Clams in Asia and the Pacific. ACIAR Monograph, 9. Canberra.

Dolorosa RG, Schoppe S. 2005. Focal benthic mollusks (Mollusca: Bivalvia and Gastropoda) of selected sites in Tubbataha Reefs National Marine Park, Palawan, Philippines. Science Diliman17: 110 .

Eliata A, Zahida F, Wibowo NJ, Panggabean LMG. 2003. Abundance of giant clam in coral reef ecosystem at Pari Island: A population comparison of 2003's to 1984's data. Biota 8 (3): 149-152.

English S, Wilkinson C, Baker, V. 1994. Survey Manual For Tropical Marine Resources. Asean-Australia Marine Science. Townsville.

Fitt WK. 1991. Mariculture of giant clams. In: Menzel W (ed.). Estuarine and Marine Bivalve Mollusk Culture. CRC Press. Boca Raton, FL.

Gomez E. 2015. Destroyed reefs, vanishing giant clams. http: //opinion.inquirer.net/84595/destroyed-reefs-vanishing-giant-clams.

Gomez ED, Mingoa-Licuanan SS. 2006. Achievements and lessons learned in restocking giant clams in the Philippines. Fish Res 80: 46-52.

Harzhauser M, Mandic O, Piller WE, Reuter M, Kroh A. 2008. Tracing back the origin of the Indo-Pacific mollusc fauna: Basal Tridacninae from the Oligocene and Miocene of the Sultanate of Oman. Palaeontology 51 (1): 199-213.

Hernawan UE, Triandiza T, Kusnadi A. 2010. Survey of the giant clams species (Tridacninae) in the coral reef of Baer Island, Southeast Moluccas. Neritic 2(2): 1-6. [Indonesian]

Hernawan UE. 2010. Study on giant clams (Cardiidae) population in Kei Kecil waters, Southeast Maluku. Widyariset 13 (3): 101-108. [Indonesian]

Hernawan UE. 2012. Taxonomy of Indonesian giant clams (Cardiidae, Tridacninae). Biodiversitas 13 (3): 118-123.

Heslinga GA. 1995. Clams to cash: how to make and sell giant clam shell products. Center for Tropical and Subtropical Aquaculture Publication, Oahu, Hawaii.

Keys JL, Healy JM. 2000. Relevance of sperm ultrastructure to the classification of giant clams (Mollusca, Cardioidea, Cardiidae, Tridacninae). Geological Society, London, Special Publications 177: 191-205.

Kinch J. 2002. Giant clams: their status and trade in Milne Bay Province, Papua New Guinea. Traffic Bull 19 (2): 1-9.

Klumpp DW, Griffiths CL. 1994. Contributions of phototrophic and heterotrophic nutrition to the metabolic and growth requirements of four species of giant clam (Tridacnidae). Mar Ecol Prog Ser 115: 103115.

Klumpp DW, Lucas JS. 1994. Nutritional ecology of the giant clams Tridacna tevoroa and T.derasa from Tonga: influence of light on filter-feeding and photosynthesis. Mar Ecol Prog Ser 107: 147-156.

Knop D. 1996. Giant Clams, A Comprehensive Guide to the Identification and Care of Tridacnid Clams. Dahne Verlag. Ettlingen.

Krell B, Skopal M, Ferber P. 2011. Koh Rong Samloem and Koh Kon Marine Environmental Assessment: Report on Marine Resources and Habitats. Marine Conservation Cambodia, Koh Rong Sanloem, Cambodia.

Kusnadi A, Triandiza T, Hernawan UE. 2008. The inventory of mollusc species and its potent on seagrass bed in Kei Kecil Islands, Southeast Moluccas. Biodiversitas 9 (1): 30-34. [Indonesian]

Latypov YY. 2013. Barrier and platform reefs of the Vietnamese coast of the South China Sea. ICES J Mar Sci 3, 23-32.

Lee S. 2014. Twenty tonnes of giant clams seized from Vietnamese fishermen. The Star Online. //www.thestar.com.my/news/nation/2014/04/14/crime-cops-clam/.

Lucas JS. 1988. Giant clams: description, distribution, and life-history. In: Copland JW, Lucas JS. (eds.). Giant Clams in Asia and the Pacific. ACIAR Monograph, 9. Canberra.

Manu N, Sone S. 1995. Breeding season of the Tongan shellfish 3. Elongated giant clam (kukukuku), Tridacna maxima. Fish Res Bull Tonga 3: 25-33.

Mingoa-Licuanan SS, Gomez ED. 2002. Giant clam conservation in Southeast Asia. Trop Coast 3: 24-56. 
Mudjiono. 1988. Catatan beberapa aspek kehidupan kima, suku Tridacnidae (Mollusca, Pelecypoda). Oseana 12 (2): 37-47. [Indonesian]

Naguit MRA, Tisera WL, Calumpong HP. 2012. Ecology and genetic structure of giant clams around Savu Sea, East Nusa Tenggara Province, Indonesia. Asian J Biodivers 3: 174-194.

Neo ML, Eckman W, Vicentuan K, Teo SLM, Todd PA. 2015. The ecological significance of giant clams in coral reef ecosystems. Biol Conserv 181: 111-23.

Neo ML, Erftemeijer PLA, van Beek JKL, van Maren DS, Teo SL-M, Todd PA. 2013. Recruitment constraints in Singapore's fluted giant clam (Tridacna squamosa) population-A dispersal model approach. PLoS ONE 8(3): e58819. DOI: 10.1371/journal.pone.0058819.

Neo ML, Loh KS. 2014. Giant clam shells 'graveyard' at Semakau Landfill. Singapore Biodivers Rec 2014: 248-249.

Neo ML, Low JKY. 2017. First observations of Tridacna noae (Röding, 1798)(Bivalvia: Heterodonta: Cardiidae) in Christmas Island (Indian Ocean). Mar.BiodiversDOI: 10.1007/s12526-017-0678-3.

Neo ML, Wabnitz CCC, Braley RD, Heslinga GA, Fauvelot C, Wynsberge SV, Andrefouet S, Waters C, Tan AS, Gomez ED, Costello MJ, Todd PA. 2017. Giant clams (Bivalvia: Cardiidae: Tridacninae): A comprehensive update of species and their distribution, current threats and conservation status. Oceanogr Mar Biol: An Annual Review 55: 87-388.

Nijman V, Spaan D, Nekaris KAI. 2015. Large scale trade in legally protected marine mollusc shells from Java and Bali, Indonesia. PLoS One: $1-18$.

Ode I. 2017. Kepadatan dan pola distribusi kerang kima (Tridacnidae) di perairan Teluk Nitanghahai Desa Morella Maluku Tengah. AgrikanUMM Ternate 10(2): 1-6. [Indonesian]

Pada DN, Boneka FB, Mamangkey GF. 2013.Identifikasi dan aspek ekologi kerang Tridacninae di perairan sekitar Pulau Venu, Kabupaten Kaimana, Provinsi Papua Barat. Jurnal Ilmiah Platax 1(2): 46-53. [Indonesian]

Pearson RG, Munro JL. 1991. Growth, mortality and recruitment rates of giant clams, Tridacna gigas and T. derasa, at Michaelmas Reef, central Great Barrier Reef, Australia. Aust J Mar Fresh Res 42: 241 262

Planes S, Chauvet C, Baldwin J, Bonvallot J, Fontaine-Vernaudon Y, Gabrie C, Holthus P, Payri C, Galzin R. 1993. Impact of tourism related fishing on Tridacna maxima (Mollusca: Bivalvia) stocks in Bora-Bora Lagoon (French Polynesia). Attol Res Bull 385: 1-14.

Poorten JJ. 2007. Results of the Rumphius Biohistorical Expedition to Ambon (1990). Part 13. Mollusca, Bivalvia, Cardiidae Zool Med Leiden 81: 259-301.

Poutiers JM. 1998. Bivalves (Acephala, Lamellibranchia, Pelecypoda). In: Carpenter KE, Niem VH (eds) FAO species identification guide for fishery purposes. The Living Marine Resources of the Western Central Pacific. Seaweeds, Corals, Bivalves and Gastropods. FAO. Rome.

Prawirowardoyo S. 1996. Meteorologi. ITB, Bandung. [Indonesian]

Ramah S, Taleb-Hossenkhan N, Bhagooli R. 2017. Differential substrate affinity between two giant clam species, Tridacna maxima and Tridacna squamosa, around Mauritius. WIO J Mar Sci Special Issue 1: $13-20$

Ramah S, Taleb-Hossenkhan N, Todd PA, Neo ML, Bhagooli R. 2018 Drastic decline in giant clams (Bivalvia: Tridacninae) around
Mauritius Island, Western Indian Ocean: Implications for conservation and management. Mar Biodivers: 1-9.

Rees M, Colquhoun J, Smith L, Heyward A. 2003. Surveys of trochus, holothuria, giant clams and the coral communities at Ashmore Reef, Cartier Reef and Mermaid Reef, Northwestern Australia. The Australian Institute of Marine Science, Townsville,Australia.

Roegner GC. 2000. Transport of molluscan larvae through a shallow estuary. J Plankton Res 22 (9): 1779-1800.

Rosewater J. 1965. The Family Tridacnidae in The Indo Pacific. IndoPacific Mollusca: Vol 1 /no. 6. The Department of Mollusca: Academy of Natural Science of Philadelphia. Pennsylvania.

Sadili D, Sarmintohadi, Ramli I, Rasdiana H, Miasto Y, Prabowo, Sari RP, Monintja M, Tery N, Annisa S. 2015. Pedoman Monitoring Populasi Kima. Direktorat Konservasi dan Keanekaragaman Hayati Laut, Direktorat Jenderal Pengelolaan Ruang laut, Kementerian Kelautan dan Perikanan. Jakarta. [Indonesian]

Savage JM, Osborne PE, Hudson MD. 2013. Abundance and diversity of marine flora and fauna of protected and unprotected reefs of the Koh Rong Archipelago, Cambodia. Cambodian J Nat Hist 2013 (3): 83-94.

Snedecor GW, Cochran WG. 1980. Statistical Methods. 7th ed. Iowa State University Press. Iowa.

Soo P, Todd PA. 2014. The behaviour of giant clams (Bivalvia: Cardiidae: Tridacninae). Mar Biol 161: 2699-2717.

Susiana, Ningsih A, Amran MA. 2014. kelimpahan dan kepadatan kima (Tridacnidae) di Kepulauan Spermonde. Agrikan Ummu-Ternate 6 (3): 55-64. [Indonesian]

Tan KS, Kastoro WW. 2004. A small collection of gastropods and bivalves from the Anambas and Natuna Islands, South China sea. Raffles Bull Zool 11: 47-54.

Triandiza T, Kusnadi A. 2013. Teknik pemijahan buatan dan pemeliharaan larva kima (Tridacna squamosa Lamarck) di Laboratorium. Oseanologi dan limnologi di Indoensia 39 (1): 1-11. [Indonesian]

Usher GF. 1984. Coral Reef Invertebrates in Indonesia: Their Exploitation and Conservation Needs. Rep. IUCN/WWF Project. Bogor.

Van Wynsberge S, Andrefouet S, Gaertner-Mazouni N, Wabnitz CCC, Gilbert A, Remoissenet G, Payri C, Fauvelot C. 2016. Drivers of density for the exploited giant clam Tridacna maxima: A meta analysis. Fish Fish 17, 567-584

Vicentuan-Cabaitan K, Neo ML, Eckman W, Teo SLM, Todd PA. 2014. Giant clam shells host a multitude of epibionts. Bull Mar Sci 90 (3): 795-796.

Wabnitz C, Taylor M, Green E, Razak T. 2003. From Ocean to Aquarium: The Global Trade in Marine Ornamental Species. UNEP-WCMC. Cambridge, UK.

Wakum A, Takdir M, Talakua S. 2017. Jenis-jenis kima dan kelimpahannya di perairan Amdui Distrik Batanta Selatan Kabupaten Raja Ampat. Jurnal Sumberdaya Akuatik Indopasifik 1: 43-51. [Indonesian]

Wells, S. 1997. Giant Clams: Status, Trade and Mariculture, and the role of CITES in management. IUCN. Gland, Switzerland and Cambridge, UK

White C, Selkoe KA, Watsons J, Siegel DA, Zacherl DC, Toonen RJ. 2010. Ocean currents help explain population genetic structure. Proc Royal Soc B: 277: 1685-1694.

Yusuf C, Ambariyanto, Hartati R. 2009. Abundance of Tridacna (Family Tridacnidae) at Seribu Islands and Manado Waters, Indonesia. Ilmu Kelautan 14(3): 150-154. [Indonesian] 